\title{
A new empirical viscosity model for composed suspensions used in experiments of sediment gravity flows
}

\section{Novo modelo empírico de viscosidade para suspensões compostas utilizadas em experimentos de fluxos gravitacionais de sedimentos}

\author{
Camila Castro $^{1}$ (D), Ana Luiza de Oliveira Borges ${ }^{1}$ (D) \& Rafael Manica (iD $^{1}$ \\ ${ }^{1}$ Universidade Federal do Rio Grande do Sul, Porto Alegre, RS, Brasil \\ E-mails: camila.castro@ufrgs.br (CC), alborges@iph.ufrgs.br (ALOB), manica@iph.ufrgs.br (RM)
}

Received: April 01, 2021 - Revised: May 18, 2021 - Accepted: June 19, 2021

\begin{abstract}
Sediment gravity flows are natural flows composed by water and sediment in which the gravitational flow acts on the sediment. The distinct physical properties of the cohesive (clay) and non-cohesive (sand) sediment, and the interaction between these particles alter the ability of the flow to resist to the movement (rheology) along time and space, represented by the viscosity of a mixture suspension. Hence, we propose to study the rheological properties of those mixtures and calculate their relative viscosity when used in the physical simulation of turbidity currents. Rheological tests were performed with various mixtures composed by water, clay and/or coal. Two equations are proposed to estimate the relative viscosity as a function of volume concentration of each sediment, the maximum packing fraction and the percentage of clay present in the mixture. The results also show an error close to $20 \%$ comparing similar models from the literature, which are satisfactory. The results also demonstrate that caution should be exercised when generalizing the use of a single model to predict the relative viscosity of suspensions. The influence of density ( $\varrho$ ), grain shape, clay percentage $\left(\mathrm{C}_{\text {clax }}\right)$, volumetric concentration $(\phi)$ and maximum packaging fraction $\left(\phi_{\max }\right)$ should be considered in the formulation of the equations.
\end{abstract}

Keywords: Relative viscosity; Rheological model; Compound suspensions; Sediment gravity flows.

\section{RESUMO}

Os fluxos gravitacionais de sedimentos são tipos de fluxos naturais compostos por água e sedimentos nos quais o fluxo gravitacional atua sobre o sedimento. As distintas propriedades físicas dos sedimentos coesivos (argila) e não coesivos (areia) e a interação entre essas partículas alteram a capacidade interna do fluxo em resistir ao movimento (reologia) ao longo do tempo e do espaço, capacidade representada pela viscosidade da suspensão de mistura. Assim, propomos estudar as propriedades reológicas dessas misturas e calcular sua viscosidade relativa utilizada na simulação física de correntes de turbidez. Foram realizados testes reológicos com várias misturas compostas por água, argila e/ou carvão. Duas equações são propostas para estimar a viscosidade relativa em função da concentração volumétrica de cada sedimento, a fração máxima de empacotamento e a porcentagem de argila presente na mistura. Os resultados também mostram um erro próximo a 20\% na comparação de modelos semelhantes na literatura, o que é satisfatório. Os resultados também demonstraram a necessidade de cautela ao generalizar o uso de um único modelo para prever a viscosidade relativa das

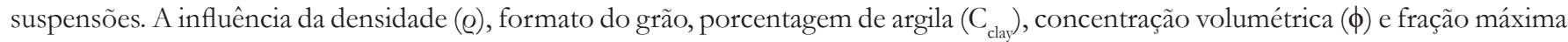
de embalagem $\left(\phi_{\max }\right)$ devem ser considerados na formulação das equações.

Palavras-chave: Viscosidade relativa; Modelos reológicos; Suspensões compostas; Fluxos gravitacionais de sedimentos. 


\section{INTRODUCTION}

Sediment gravity flows (SGF) are natural flows in which the gravitational flow acts on the sediment, e.g., turbidity currents and debris flows (Middleton \& Hampton, 1973). They are the main agent of sediment transport into deep water through events of great magnitude, capable of breaking submarine cables such as the Grand Banks event (Simpson, 1997). SGF is the most important process of clastic accumulation in the seabed in areas of hydrocarbon exploration (Normark et al., 1993; D’Ávila \& Paim, 2003). Also, the occurrence of SGF in lakes or water reservoirs causes the deposition of sediment near the foot of the dam, obstructing the water intake and decreasing the reservoir useful volume (Schleiss et al., 2016).

Sediment gravity flows can also be described as the relative motion between layers of fluids with different densities due to the concentration of suspended particles. Since SGF are composed by sediments with distinct physical properties, such as cohesive (clay) and non-cohesive (sand) sediments, the inner ability of the flow to resist to the movement, i.e., the viscosity of a mixture suspension, can be altered. The intensity of the interaction between these particles may also change with time and space. Hence, the rheology, science that studies the deformation and flow of solids and fluids (gases or liquids), plays an important role in the understanding of these natural phenomena. On the other hand, the rheological characterization of particulate mixtures (in the case of SGF) is complex. Dott (1963) recognized the importance of rheology in the classification of such gravitational flows. Subsequently, Lowe (1979, 1982), Postma et al. (1988), Shanmungan (1996), Mulder \& Alexander (2001), Dasgupta (2003), Gani (2004), Manica (2009) and Talling et al. (2012) included rheological properties in the classification of the currents. In fact, sediment gravity flows classification is divided into two groups, mainly because of the rheological behavior of mixture suspensions. Turbidity currents are usually classified as Newtonian Flows, and the debris flows as non-Newtonian Flows (Table 1). The Newtonian behavior implies in linear relationship between shear stress $(\tau)$ and shear rate $(\dot{\gamma})$, zero yield strength and constant coefficient of dynamic viscosity; while non-Newtonian behavior includes all other situations, i.e., linear relationship shear stress and shear rate with the presence of yield strength $\left(\tau_{0}\right)$ (e.g., Bingham model) or power law relationship with the presence of yield strength (e.g. Hershel-Bulkley model). Yet, flows without yield strength and non-Newtonian behavior are classified as (e.g. pseudo-plastic or dilatant models). All nonNewtonian models imply in non-constant coefficient of viscosity, called apparent viscosity $\left(\mu_{\mathrm{ap}}\right)$.
To understand and estimate the rheological behavior of mixture we need to comprehend the relation between sediment volume concentration and viscosity of the mixture, called relative viscosity of suspensions and how it is determined (Table 2). Relative viscosity is a non-dimensional parameter of the viscosity of the suspension divided by the viscosity of another fluid used as reference (e.g. freshwater).

Einstein (1905), through a theoretical basis on Brownian movement, pioneered an equation that relates the volumetric concentration $(\phi)$ and the relative viscosity $\left(\mu_{\mathrm{r}}\right)$. Einstein's expression (see Table 2) does not consider the size of the particle, the position or the effect of the interaction between particles and, for this reason, this expression is valid only for suspensions with low volumetric concentration (less than $2 \%$ ). However, the particle shape information is contained in the Einstein coefficient, known as the intrinsic viscosity $\left(\mu_{i}\right)$ value of 2.5 for spheres. Later, Batchelor \& Green (1972) expanded this model and included higher order terms that represent the effect of other particles, being valid for volumetric concentrations between $2 \%$ to $10 \%$. For moderately concentrated suspensions $(\phi<45 \%)$ with monodispersed and polydispersed sphere suspension data, Chong et al. (1971) proposed an equation based on a theoretical and experimental approach, which also considers the maximum packing fraction $\left(\phi_{\max }\right)$. As the fraction of solids increases, the particles come into closer contact and the many interactions between them must be considered. In addition, for volumetric concentrations greater than 20\%, Maron \& Pierce (1956) developed a model based on a theoretical and experimental approach that considers these interactions between the particles (viscous energy dissipation and Brownian motion). For more concentrated suspensions, Dougherty \& Krieger (1959) proposed an empirical equation that presents the intrinsic viscosity coefficient $\left[\mu_{i}\right]$ which expresses the effect of an isolated particle, i.e., without influence of molecular interactions on solvent (Equation 7).

Manica (2009) proposed three empirical equations to estimate the relative viscosity from data of kaolin composites and glass beads used in the study of turbidity currents, considering the volumetric concentration $(\phi)$, percentage of clay $\left(C_{c l d}\right)$ and the shear rate $(\gamma)$. He identified a rheological threshold which divides the Newtonian behavior of the mixtures (e.g. turbidity currents) from the non-Newtonian behavior (e.g. debris flow).

Santamaría-Holek \& Mendoza (2010) proposed a theoretical model that can be applied to particles of any shape, provided that the intrinsic viscosity $\left(\mu_{i}\right)$ is known (Equations 11 and 12). The effect of the interaction between the particles is introduced by the effective volumetric concentration $\left(\phi_{\mathrm{ef}}\right)$. Brouwers (2010) presents a theoretical expression based on particle geometry for

Table 1. Rheological models classification. The variables are: shear stress $(\tau)$ and shear rate $(\dot{\gamma})$ apparent viscosity $\left(\mu_{\text {ap }}\right)$ and yield strength $\left(\tau_{0}\right) ; \mathrm{k}$ and $\mathrm{n}$ are power law coefficients.

\begin{tabular}{|c|c|c|c|c|}
\hline Type & \multicolumn{2}{|c|}{ Rheological models } & Yield strength $\left(\tau_{0}\right)$ & Eq. \\
\hline \multirow{3}{*}{ Non-Newtonian } & Bingham & $\tau=\tau_{0}+\mu_{a p} \dot{\gamma}$ & Yes & (1) \\
\hline & Herschel Bulkley & $\tau=\tau_{0}+k \dot{\gamma}^{n}$ & Yes & (2) \\
\hline & $\begin{array}{c}\text { Pseudo-plastic }(n<1) \\
\text { Dilatant }(n>1)\end{array}$ & $\tau=k \dot{\gamma}^{n}$ & No & (3) \\
\hline Newtonian & Newton & $\tau=\mu \dot{\gamma}$ & no & (4) \\
\hline
\end{tabular}


Table 2. Usual relative viscosity equations found in the literature.

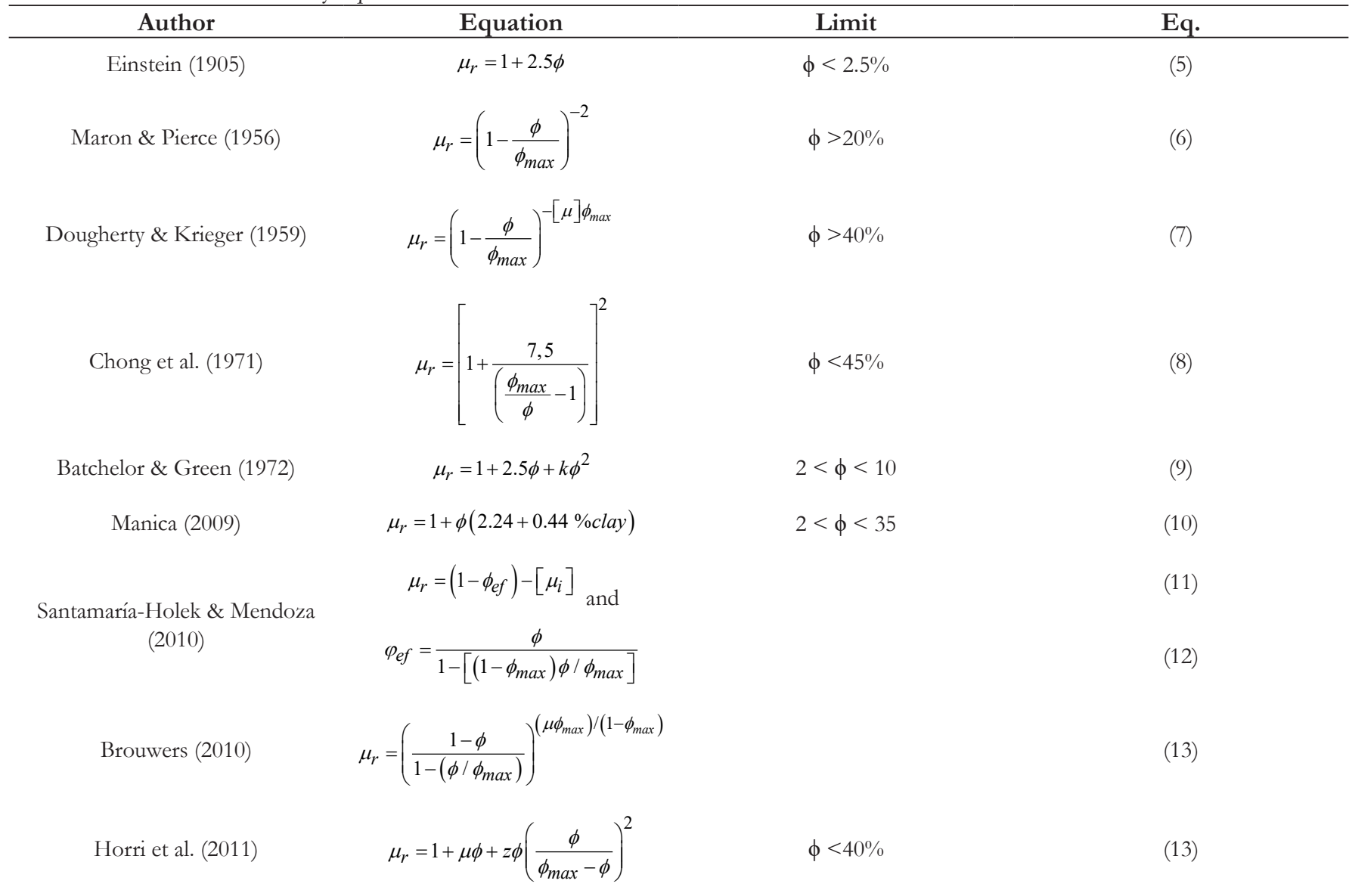

mixtures with low volumetric concentration of monodispersed particles. Horri et al. (2011) adjusted an experimentally-obtained equation for ceramic suspensions $(\phi<40 \%)$ using a parameter $\left(\phi /\left(\phi_{\max }-\phi\right)\right)$ originally proposed by Dabak \& Yucel (1986). The term in the denominator represents the space available for the particles to move and the parameter $\mathrm{z}$ is a constant that can be estimated experimentally. Rutgers (1962) identified 96 models in the literature to calculate this parameter and Table 2 summarizes the some well-known applied in sciences field, as well as in the water-sediment mixtures studies.

However, we question whether: 1) the equations commonly used to evaluate the viscosity of suspensions can be applied in the case of granular suspensions, such as those employed in the physical simulation of sediment gravity flows (mixtures of water, clay and/ or coal or other granular material); 2) the equations established for one type of sediment (e.g. quartz) can be correctly extrapolated to other sediments (e.g. coal). Mineral coal is regularly used as a substitute for quartz in the laboratory experiments, because coal presents low density compared with natural sediment, allowing the use of a larger grain size comparing with the natural ones (e.g. quartz). Literature examples of the applied technique in a small-scale experiment is reported in Baas et al. (2014), Manica \& Borges (2015), Fick et al. (2017), Boffo et al. (2019).

Thus, this work proposes a rheological model for the calculation of relative viscosity of mixtures used in the physical simulation of sediment gravity flows obtained via rheological test mixtures composed of water, clay and/or coal with various volumetric concentrations and the presence of clay. Also, we compare the viscosity data of mixtures used with well-known rheological equations from the literature. We also propose a rheological equation from the experimental data of relative viscosity of mixtures composed of kaolin and/or mineral coal, which could also be extrapolate to natural sediment gravity flows.

\section{APPARATUS AND METHODOLOGY}

To characterize the relative viscosity of mixtures proposed in this work, we tested fresh water, kaolin and/or mineral coal mixtures at the following volumetric concentrations $(\phi)(5,10,15$, 20, 25 and $30 \%$ ). Also, several proportions of coal and kaolin were used $(0: 100,15: 85,25: 75,50: 50,75: 25,85: 15$ and 100:0). For each of the 42 mixtures suspension tested, five repetitions were performed in order to minimize the random errors of the tests (i.e. $<5 \%$ ), totaling 210 rheometric tests. The physical characteristics of the minerals play a significant role in the rheological behavior of the mixtures that compose sediment gravity flows. Mineral coal has a density (@) of $1190 \mathrm{~kg} \cdot \mathrm{m}^{-3}$, grain size ranges from 0.07 to $400 \mu \mathrm{m}$ and median diameter $\left(\mathrm{d}_{50}\right)$ of $47.98 \mu \mathrm{m}$. Kaolin has a density (e) of $2600 \mathrm{~kg} \cdot \mathrm{m}^{-3}$, grain size from 0.04 to $90 \mu \mathrm{m}$ and median diameter $\left(\mathrm{d}_{50}\right)$ of $8.22 \mu \mathrm{m}$. Freshwater has density of $1000 \mathrm{~kg} \cdot \mathrm{m}^{-3}$. Also, the dynamic viscosity of fresh water $\left(\mu_{0}\right)$ is $\mu_{0}=10^{-3} \mathrm{~Pa}$.s at $20^{\circ} \mathrm{C}$, used as reference value in this work.

The rheological characterization data were acquired with the use of a controlled rotational rheometer Bohlin C-VO with external control of temperature. Three spindles were tested and then chosen for the test. The cone-and-plate (CP 4/40) was used for lower volumetric concentration $(\phi<20 \%)$. Vane spindle was 
used for more concentrated clay suspensions $(\phi>20 \%)$ and concentric cylinder (CC25) for more concentrated suspensions without clay $(\phi>20 \%)$. The Rheometer Bohlin allows various scenarios of simulation through dedicated software (voltage range to be applied, time and type of test). We performed either shear stress control or shear rate control, increasing or decreasing values. During the test, the software plots the rheograms, i.e. shear stress $(\tau)$ versus shear rate $(\gamma)$ applied experimental data, therefore the experimentalist can follow the results instantaneously.

Initially, each mixture was previously prepared in beakers. Then a selected spindle was placed on the rheometer. With the use of a syringe, approximately $1.5 \mathrm{ml}$ (cone and plate) or $10 \mathrm{ml}$ (vane and concentric cylinder) of mixture was injected between the geometries of measurement for the spindle and the rheometer. The parameters for each test were adjusted in the rheometer software application and then the test occurred (shear stress control with 20 min total time for each run). With the set of five curves on the rheogram obtained in the tests, a rheological model was fit and a single series of data was obtained. The choice of the best model, among the different rheological models available on the rheometer software (non-Newtonian models and the Newtonian model), was taken based on higher value $(\max =1)$ of the statistical parameter called the coefficient of determination $\left(\mathrm{R}^{2}\right)$, which indicates the best-fit model. Finally, we also consider the shear rate $(\gamma)$ value of $25 \mathrm{~s}^{-1}$ to calculate the relative viscosity values in order to directly compare the results with data presented in Manica (2009), as well as others literature models (Table 2).

\section{RESULTS}

\section{Rheological behavior of the mixtures}

The rheological mixtures curves measured on the experiments presented two classical rheological behaviors depending of presence of clay and concentration. For concentration mixtures below $10 \%$ $(\phi<10 \%)$, the Newtonian model Equation 4 fit better for all mixtures. For highly concentrated mixtures $(\phi \sim 30 \%)$, the best fitted model was Herschel-Bulkley Equation 2 with a coefficient of determination $\left(\mathrm{R}^{2}\right)$ around 0.97 . This mixture presented yield strength found in plastic rheologic behavior (Table 1). Mixtures between $15<\phi<25 \%$ presented both Newtonian and nonNewtonian, depending on the presence of clay. Thus, a rheological threshold was determined for all mixtures simulated (Figures 1A-G).
We can notice the presence of two rheological models describe above, a linear Newtonian and non-linear Herschel-Bulkley model. For all non-Newtonian mixtures, we plotted an apparent viscosity $\left(\mu_{\text {ap }}\right)$ versus shear rate (Figure 2$)$, showing the direct influence of the mixture concentration $(\phi)$ on the high values of viscosities.

Table 3 shows the rheological classification for all 42 mixtures, varying concentration and clay presence. The white background represents mixtures with Newtonian behavior and gray background represents mixtures with behavior according to the Herschel-Bulkley model. In addition, Table 3 presents the relative viscosity $\left(\mu_{\mathrm{r}}\right)$ experimental data at a shear rate $(\gamma)$ of $25 \mathrm{~s}^{-1}$ and the maximum packing fraction $\left(\phi_{\max }\right)$ obtained by the Liu (2000) methodology.

\section{Determination of relative viscosity by analytical equations}

Seven equations for the calculation of relative viscosity (Table 2) were chosen to compare our results and verify if they characterize well our mixtures. These equations present various scenarios and parameters in their design (experimentally and/or analytically) and the applicability (for low and/or high concentrations).

The comparison between our results and the various models applied was plotted in Figures 3 and 4. Qualitatively, we observed that the model of Chong et al.- Equation 8, adjusted better to our experimental results. In fact, the quantitative results shown in Table 4 demonstrated the Mean, Standard Deviation, Maximum and Minimum values of relative error among all models. Again, Chong et al. (1971) showed the lowest values (around 20\% mean), which is accepted for rheological measurements. Since the Chong model was idealized for spherical particles, the results seem to be reasonable and coherent, as the shape of the coal is semi-angular and semi-rounded (Manica, 2002).

When we increased the proportion of coal in the mixture $(\geq 75 \%)$, the relative viscosity values of the mixtures approached equation 8 proposed by Chong et al. (1971), and also Equation 6, the Maron \& Pierce (1956) model, with errors ranging from 8 to $24 \%$ (see bold numbers in Table 4). Since both models were designed for spherical particles, this demonstrates that the effect of the particle shape also plays a significant role in the rheology of a mixture.

Table 3. Relative viscosity $\left(\mu_{\mathrm{r}}\right)$ experimental data at a shear rate of $25 \mathrm{~s}^{-1}$. The gray background indicates a Herschel-Bulkley models and the white a Newtonian Model.

\begin{tabular}{|c|c|c|c|c|c|c|c|c|}
\hline \multicolumn{2}{|c|}{ Mixture } & \multirow{2}{*}{$\begin{array}{c}\text { Maximum } \\
\text { packing } \\
\text { fraction }\end{array}$} & \multicolumn{6}{|c|}{ Volumetric concentration $\phi(\%)$} \\
\hline$\%$ Kaolin & $\%$ Coal & & 5 & 10 & 15 & 20 & 25 & 30 \\
\hline 100 & 0 & 0.33 & 2.53 & 4.27 & 20.69 & 60.59 & 233.3 & 756.5 \\
\hline 85 & 15 & 0.35 & 2.22 & 3.26 & 12.99 & 41.23 & 127.9 & 362.5 \\
\hline 75 & 25 & 0.38 & 2.12 & 2.91 & 4.09 & 35.61 & 70.4 & 173.3 \\
\hline 50 & 50 & 0.40 & 1.75 & 2.42 & 3.33 & 11.77 & 19.8 & 47.3 \\
\hline 25 & 75 & 0.37 & 1.63 & 2.12 & 2.69 & 3.54 & 8.8 & 24.9 \\
\hline 15 & 85 & 0.40 & 1.34 & 1.93 & 2.48 & 3.30 & 5.1 & 11.0 \\
\hline 0 & 100 & 0.50 & 1.31 & 1.81 & 2.06 & 2.82 & 3.5 & 7.3 \\
\hline
\end{tabular}



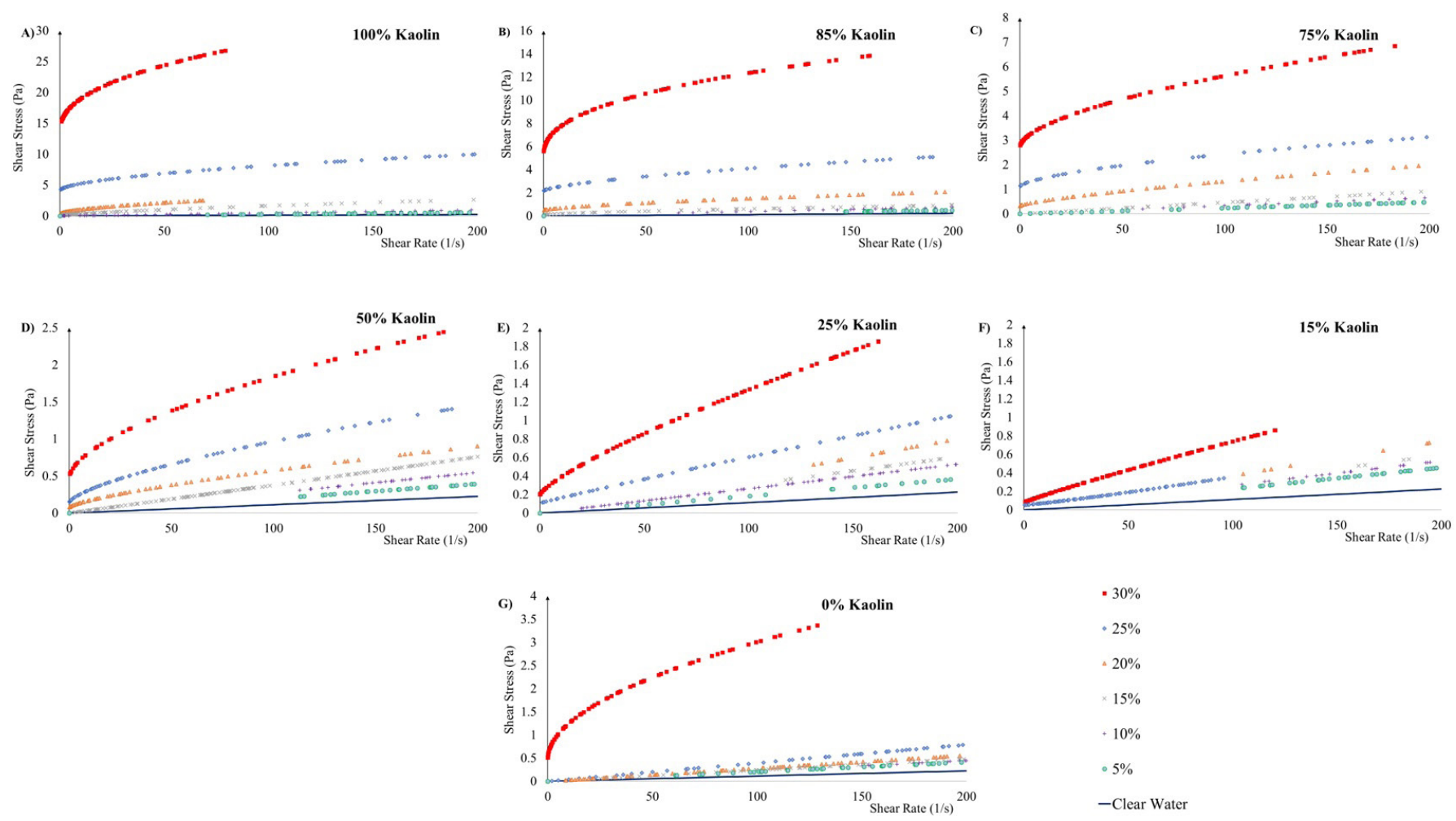

$\cdot 30 \%$

$\cdot 25 \%$

$\triangle 20 \%$

$\times 15 \%$

$\cdot 10 \%$

$\cdot 5 \%$

- Clear Water

Figure 1. Rheological diagram (shear stress and shear rate relationship) for all mixtures.
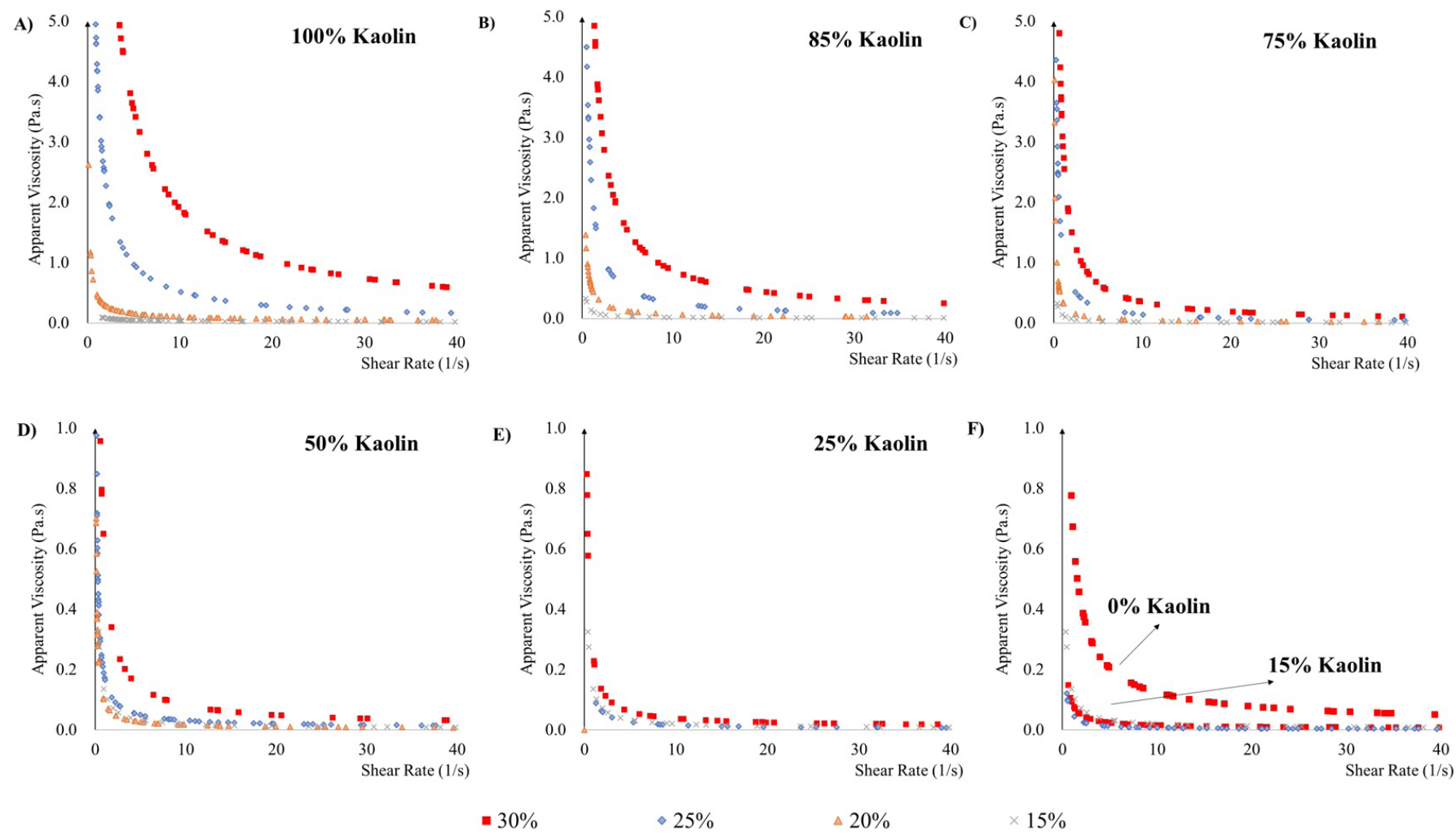

Figure 2. Apparent viscosity related with shear rate for all Herschel-Bulkley models obtained in the experiments.

\section{Empirical equation model to estimate relative viscosity}

Nevertheless, there is good agreement between our data and the Chong Model - Equation 8. The relative error was high enough to fully estimate the relative viscosity of kaolin/coal mixtures used in physical simulation of sediment gravity flows. We propose therefore a new empirical model to estimate the relative viscosity of this type of kaolin and/or coal suspension. To obtain the empirical model, the rheologic data were treated as follows. 

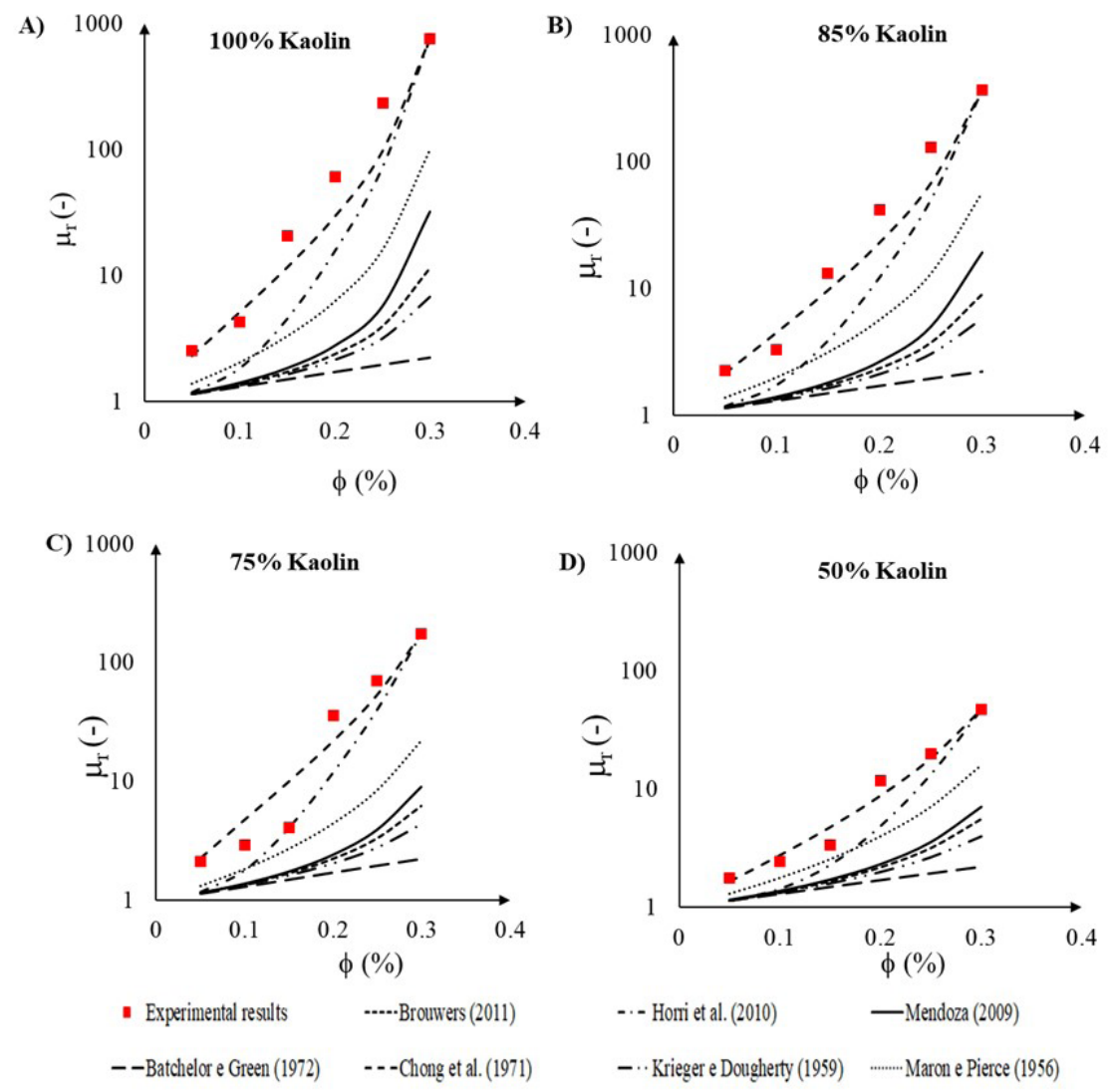

Figure 3. Experimental data of the relative viscosity of the mixtures as a function of volumetric concentration and the comparison with seven equations proposed in the literature. The mixtures composed by: (A) 100\% kaolin; (B) 85\% kaolin; (C) 75\% kaolin; (D) $50 \%$ kaolin.
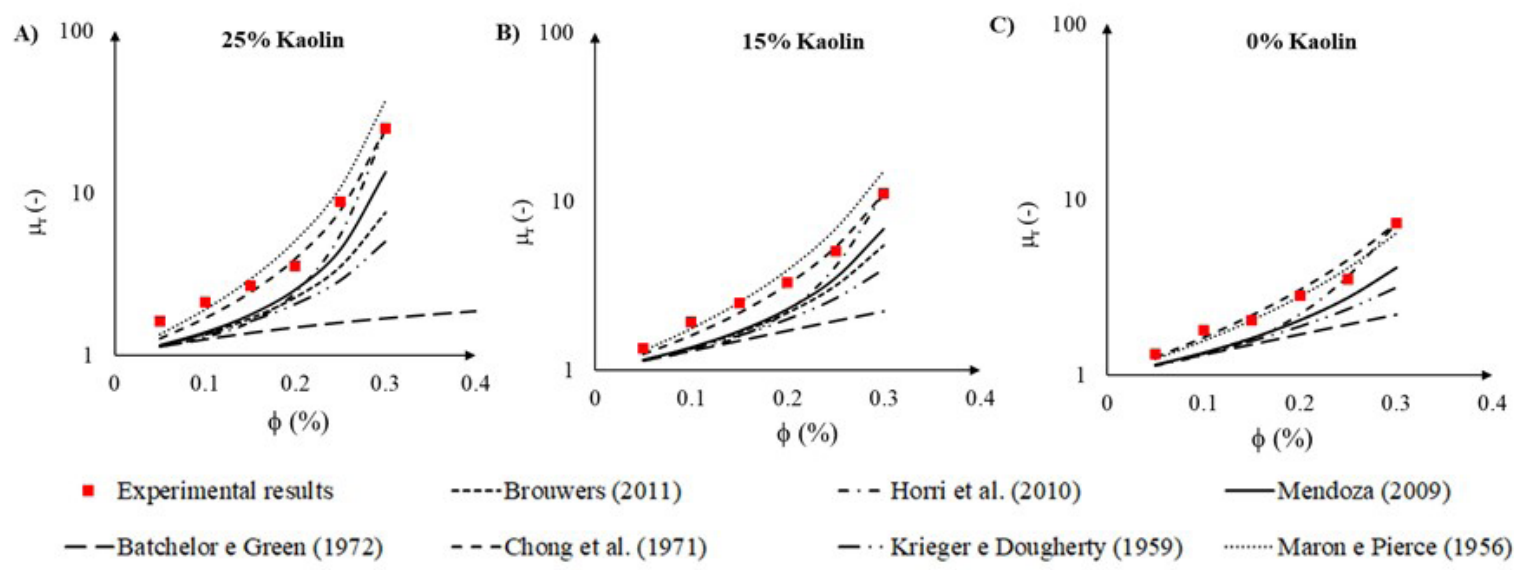

$$
\begin{aligned}
& \text { - - Horri et al. (2010) } \\
& \text { - - Krieger e Dougherty (1959) }
\end{aligned}
$$

- Mendoza (2009)

Figure 4. Experimental data of the relative viscosity of the mixtures as a function of volumetric concentration and the comparison with seven equations proposed in literature: (A) 25\% kaolin; (B) 15\% kaolin; (C) $0 \%$ kaolin.

In general, models for predicting relative viscosity as a function of the concentration of particles consider distinct behavior for low and high volumetric concentrations. The limit for high concentration is given by Equation 14, which shows that the relative viscosity of a suspension tends to infinite when the concentration of sediment approaches the maximum packaging fraction $\left(\phi_{\max }\right)$ (Chong et al., 1971).

$$
\lim _{\phi \rightarrow \phi_{\max }} \mu_{r}=\infty
$$

Because of sediments present distinct densities, they influence on the mixture used in experiments is not linear. To verified that, we determine the volumetric concentration of kaolin $\left(\phi_{\text {clax }}\right)$ and coal $\left(\phi_{\text {Coal }}\right)$, i.e, the influence of each sediment on the mixture, 
Table 4. Relative Viscosity error between the experimental results and seven models from literature.

\begin{tabular}{|c|c|c|c|c|c|c|c|c|}
\hline \multicolumn{2}{|c|}{ Mixture } & Einstein & M\&P & Chong & $\mathrm{B} \& \mathrm{G}$ & $\mathrm{S}, \mathrm{H} \& \mathrm{M}$ & Browers & Horri \\
\hline \multirow{2}{*}{\multicolumn{2}{|c|}{$\%$ Kaolin }} & \multicolumn{7}{|c|}{ Relative Error (\%) } \\
\hline & & Equation 5 & Equation 6 & Equation 8 & Equation 9 & Equation 11 & Equation 12 & Equation 13 \\
\hline \multirow[t]{2}{*}{100} & Mean & 86 & 76 & 32 & 86 & 84 & 85 & 56 \\
\hline & St. Dev. & 19 & 21 & 25 & 19 & 18 & 19 & 29 \\
\hline \multirow[t]{2}{*}{85} & Mean & 83 & 69 & 27 & 82 & 79 & 80 & 50 \\
\hline & St. Dev. & 22 & 25 & 18 & 22 & 22 & 22 & 12 \\
\hline \multirow[t]{2}{*}{75} & Mean & 77 & 62 & 46 & 76 & 73 & 74 & 32 \\
\hline & St. Dev. & 23 & 28 & 53 & 23 & 23 & 23 & 24 \\
\hline \multirow[t]{2}{*}{50} & Mean & 70 & 45 & 16 & 68 & 62 & 64 & 33 \\
\hline & St. Dev. & 24 & 22 & 15 & 24 & 22 & 23 & 11 \\
\hline \multirow[t]{2}{*}{25} & Mean & 59 & 24 & 10 & 56 & 37 & 45 & 30 \\
\hline & St. Dev. & 20 & 7 & 10 & 19 & 8 & 12 & 4 \\
\hline \multirow[t]{2}{*}{15} & Mean & 51 & 17 & 8 & 47 & 29 & 34 & 23 \\
\hline & St. Dev. & 20 & 14 & 7 & 18 & 8 & 10 & 10 \\
\hline \multirow[t]{2}{*}{0} & Mean & 42 & 8 & 10 & 37 & 25 & 25 & 15 \\
\hline & St. Dev. & 15 & 7 & 10 & 12 & 6 & 6 & 9 \\
\hline \multirow[t]{4}{*}{ Totals } & Max & 83 & 69 & 46 & 82 & 79 & 80 & 50 \\
\hline & Min & 42 & 8 & 8 & 37 & 25 & 25 & 15 \\
\hline & Mean & 67 & 43 & 21 & 64 & 56 & 58 & 34 \\
\hline & St. Dev. & 17 & 27 & 14 & 18 & 25 & 24 & 14 \\
\hline
\end{tabular}

Note: St. Dev. $=$ Standard Deviation.
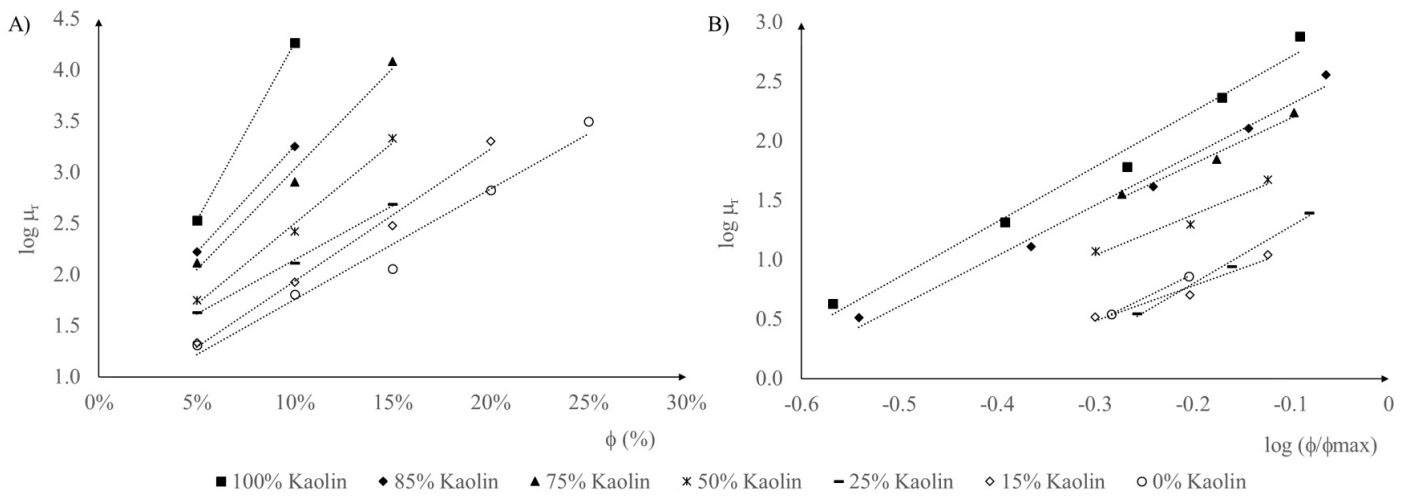

Figure 5. (A) Relation between the relative viscosity $\left(\mu_{\mathrm{r}}\right)$ and volumetric concentration $(\phi)$ for all Newtonian flows; (B) Logarithm of the relative viscosity as a function of parameter $\phi / \phi_{\max }$ for mixtures with non-Newtonian behavior.

and we related it with the percentage of kaolin $\left(C_{c l a s}\right)$ and coal $\left(\mathrm{C}_{\text {coal }}\right)$ present in the mixture used in the experiments (Equation 15 and 16 , respectively).

$\phi_{\text {clay }}=0.892\left(C_{\text {clay }}\right)^{1.348}$

$$
\phi_{\text {coal }}=1.042\left(C_{\text {coal }}\right)^{0.674}
$$

Based on the rheometer results, the relative viscosity $\left(\mu_{\mathrm{r}}\right)$ data of all Newtonian behavior curves were plotted relative to the mixture volumetric concentration $(\phi)$ (Figure 5A). Then, a multiple regression $\left(\mathrm{R}^{2}>93.74 \%\right)$ was applied on the data (Figure 5A) to generate a relationship between the relative viscosity, the mixture volumetric concentration $(\phi)$ and volumetric concentration of kaolin $\left(\phi_{\text {clay }}\right)$ and coal $\left(\phi_{\text {Coal }}\right)$. The result is summarized in Equation 17. This relationship is important because volumetric concentration is a key parameter on sediment gravity flows experiments.

$$
\mu_{r}=1+\phi\left(31.53 \phi_{\text {clay }}+9.43 \phi_{\text {coal }}\right)
$$

For Non-Newtonian behavior, the relation between the relative viscosity and the ratio between volumetric concentration $(\phi)$ and the maximum packing fraction was defined according to the power law for non-Newtonian mixtures (Equation 18).

$$
\mu_{r}=\alpha\left(\frac{\phi}{\phi_{\max }}\right)^{\beta}
$$

By performing the linearization, via a logarithmic processing of Equation 18, we obtain Equation 19, whose linear adjustment of the data can be seen in Figure 5B. 
$\log \mu_{r}=\beta \log \left(\frac{\phi}{\phi_{\max }}\right)+\log \alpha$

where $\beta$ is the gradient of the line (power law that relates $\mu_{\mathrm{r}}$ and $\left.\phi / \phi_{\max }\right)$ and $\alpha$ is the independent variable of the linear adjustment (interception point with axis vertical).

Table 5 summarizes the coefficient of determination of linear fitted line $\left(\mathrm{R}^{2}\right)$, as well as the gradient $(\beta)$ and intercept point $(\alpha)$.

With data from Table 5 we correlated the parameters $\alpha$ and $\beta$ with the percentage of clay present in the mixtures. Both parameters $\alpha$ and $\beta$ present best fit for an exponential trend with percentage of clay $\left(C_{\text {cla }}\right)$ with $\mathrm{R}^{2}=0.9838$ and $\mathrm{R}^{2}=0.9826$, respectively (Equations 20 and 21).

$$
\alpha=13,81 e^{4,4954\left(C_{\text {clay }}\right)}
$$

$$
\beta=2,664 e^{0.5341\left(C_{\text {clay }}\right)}
$$

Table 5. Values of intercept $(\alpha)$, gradient $(\beta)$ and coefficient of determination $\left(\mathrm{R}^{2}\right)$ of the linearized equations of Figure 4B.

\begin{tabular}{cccc}
\hline \%Clay & $\boldsymbol{\alpha}$ & $\boldsymbol{\beta}$ & $\mathbf{R}^{\mathbf{2}}$ \\
\hline 100 & 1488.7 & 4.62 & 0.9840 \\
85 & 540.4 & 4.25 & 0.9883 \\
75 & 382.2 & 3.87 & 0.9812 \\
50 & 113.7 & 3.39 & 0.9604 \\
25 & 57.5 & 4.79 & 0.9909 \\
15 & 23.5 & 2.94 & 0.9495 \\
0 & - & - & - \\
\hline
\end{tabular}

Finally, substituting Equations 20 and 21 in Equation 18, the relative viscosity of the suspensions with non-Newtonian behavior is defined according to Equation 22.

$\mu_{r}=13.81 e^{4.49\left(C_{\text {clay }}\right)}\left(\frac{\phi}{\phi_{\max }}\right)^{\left[2.66 e^{0.53\left(C_{\text {clay }}\right)}\right]}$

Figure 6A summarizes the equations here proposed for the new empirical model for estimating the relative viscosity of the suspensions for kaolin and clay used in physical simulation, represented by Equations 17 and 22. A rheological threshold indicates the transition behavior based on the initial mixtures. It is important to noticed this threshold is not an exact limit, but we have to consider a range of variation $( \pm 15 \%)$ in which the line can move. Further investigations could define better this threshold. Based on this diagram, the type of rheological behavior can be predicted for experimental runs.

\section{DISCUSSION}

Models for predicting relative viscosity as a function of particle volume concentration must satisfy two conditions. First, the relative viscosity must obey the relation proposed by Einstein (1905), approaching one when the volumetric concentration tends to zero. Second, the relative viscosity tends to infinite when the volumetric concentration approaches the maximum packing fraction $\left(\phi_{\max }\right)$, as present in Equation 14 of Chong et al. (1971).

The viscosity of a mixture is an intrinsic property of the material. The main problem with the above-mentioned conditions is the lack of generalization for all types of mixtures, i.e. the viscosity of a mixture of water and sediment is not a function dependent only on the solid fraction (Pabst, 2004).

On the other hand, we can consider infinite correlations between the physical characteristics of the particles (e.g. particle
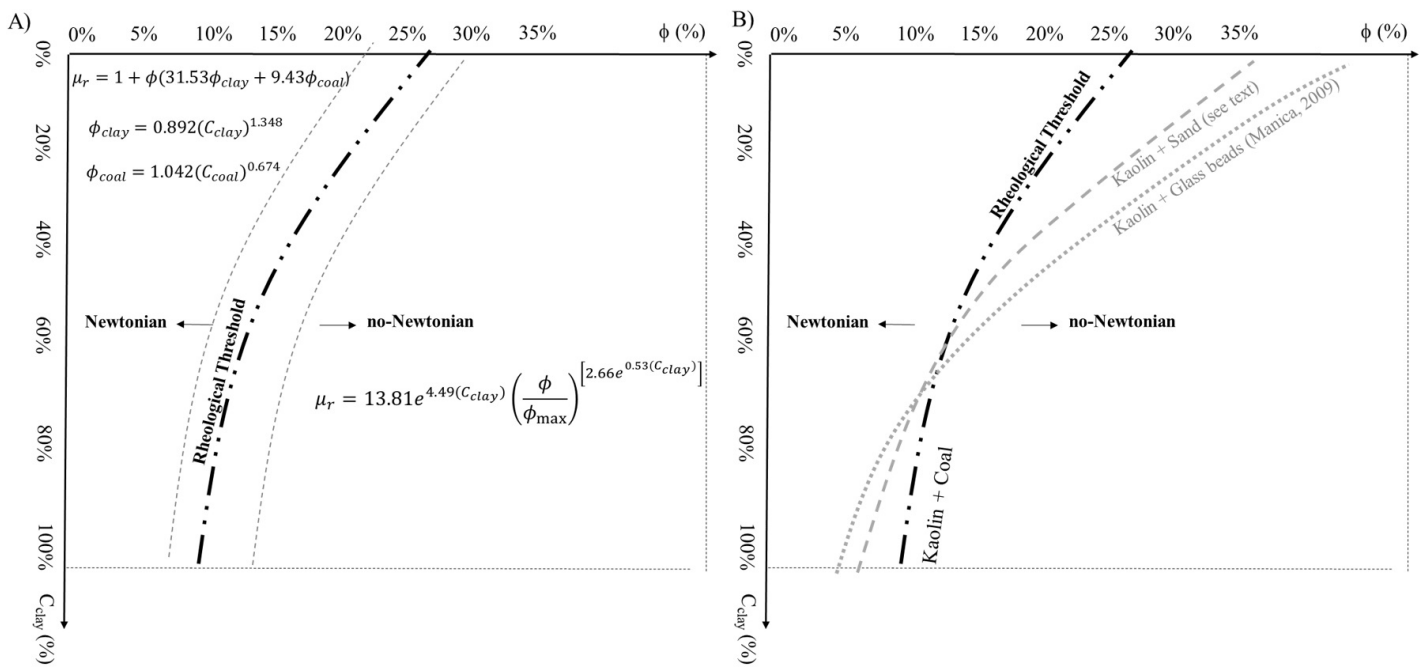

Figure 6. (A) Relative viscosity of the mixture suspensions proposed in this work and the rheological threshold between Newtonian and Non-Newtonian behavior. The dashed line represents a threshold variation of $\pm 15 \%$; (B) Rheological threshold for three mixtures composed of cohesive and non-cohesive material. Kaolin and coal mixtures (red dotted line), present work; kaolin and sand mixtures (Coussot \& Piau, 1994; Kiryu, 2006; Santos 2003) (blue traced line) and kaolin and glass beads (black line) (Manica, 2009). 
size distribution, particle shape), with other components of the mixtures. Qualitatively, a suspension of water and sediment is considered a single-phase mixture, i.e. a liquid matrix containing the solid particles (Coussot, 1997). Nevertheless, even where other microstructural aspects are important, Pabst (2004) stated that the particle shape information is contained in the Einstein coefficient, known as the intrinsic viscosity $\left(\mu_{i}\right)$ value of 2.5 for spheres. For non-spherical particles, this value changes (Barnes et al., 1993). Likewise, particle size distribution and/or particle arrangement information is contained in the maximum packing fraction $\left(\phi_{\text {max }}\right)$. The empirical model proposed in this study tried to correlate all the parameters described above in a single equation. This makes the model useful for application in the laboratory and for simulation of sediment gravity flows such as presented by Boffo et al. (2019).

The use various materials and mixtures in the experiments is usual for sediment gravity flow physical modeling. Manica (2009) ran experiments using glass beads $\left(\varrho=2600 \mathrm{~kg} \cdot \mathrm{m}^{-3}, \mathrm{~d}_{50}=44 \mu \mathrm{m}\right.$ well rounded particles) and kaolin $\left(\varrho=2600 \mathrm{~kg} \cdot \mathrm{m}^{-3}, \mathrm{~d}_{50}=8 \mu \mathrm{m}\right.$ angular particles) with similar proportions to the mixtures used in this work. For comparison, we obtained the maximum packing fraction (Liu's methodology) for his mixtures (Table 6)

Table 6 shows the maximum packaging fraction of the kaolin at 0.32 for the Manica (2009) work. This value is compatible with this study (0.33) and with the literature (0.29 to 0.33) (Beruto et al., 2009). In addition, similar trend was observed in both sets of mixtures: decreasing value of the maximum packaging fraction with the increase of kaolin in the mixture. Finally, the value of 0.62 found for the glass beads mixture ( $0 \%$ kaolin) is consistent with the value of 0.605 from the literature (Barnes et al., 1993)

Regarding the relative viscosity, we compared our Equation 22 used for kaolin and coal with Manica (2009) Equation 10 (kaolin and glass beads) and also with the other equations from the literature presented in Table 2. Comparative analysis of the data shows that the equations proposed in this work predict the relative viscosity for the mixture with 100\% kaolin and for the mixture with 50\% kaolin and $50 \%$ glass beads with a relative error $\sim 10 \%$. This result is linked with the kaolin used by Manica (2009) with physical characteristics close to the kaolin used in this work, from which the proposed empirical equation was conceived. This result is also due to the cohesive physical characteristic of kaolin, which plays a predominant role in the rheology of a mixture with non-colloidal particles. However, for mixtures with only glass beads, our model

Table 6 Maximum packing fraction comparison between this work (mixture kaolin and coal) and Manica (2009) mixture kaolin and glass beads).

\begin{tabular}{cccc}
\hline Mixture & & \multicolumn{2}{c}{ Maximum packing fraction $\left(\phi_{\max }\right)$} \\
\cline { 4 - 4 } \cline { 3 - 3 } \% Kaolin & This work & Manica $(\mathbf{2 0 0 9})$ \\
\hline $\mathbf{1 0 0}$ & 0.33 & 0.32 \\
$\mathbf{8 5}$ & 0.35 & 0.34 \\
$\mathbf{7 5}$ & 0.38 & 0.37 \\
$\mathbf{5 0}$ & 0.40 & 0.48 \\
$\mathbf{2 5}$ & 0.37 & 0.60 \\
$\mathbf{1 5}$ & 0.40 & 0.58 \\
$\mathbf{0}$ & 0.50 & 0.62 \\
\hline
\end{tabular}

presented no good agreement. Our equation overestimates the relative viscosities of the mixtures (error $>40 \%$ ). This result was expected as the glass beads used by Manica (2009) have significant difference in density and shape relative to the mineral coal used in this work. In fact, the importance of the sediment characteristics in the composition of an equation to estimate the viscosity must be considered. For instance, the model of Chong et al. (1971) was originally designed for spherical particles, while the model of Horri et al. (2011) has a constant that can be adjusted according to the experimental data. Both models provided a better fit for the composite glass beads mix, although these equations have been designed for a mixture with non-colloidal particles.

Regarding the results from the present work, we verified that for the mixtures with less than $25 \%$ of kaolin (i.e. $\mathrm{C}_{\text {coal }}>75 \%$ ), the models of Chong et al. (1971) and Maron \& Pierce (1956) are a tool to obtain a relative viscosity estimate, but not complete for all flows. The model proposed by Horri et al. (2011) was designed for ceramic suspensions, but it did not satisfactorily represent mixtures with $100 \%$ kaolin as expected. We can discuss, therefore, that it is often not plausible to generalize these formulations to other flows, because they do not consider other significant effects that occur in a proper suspension. With respect to the other models applied, we could not successfully predict the relative viscosity of the mixtures used in this study, as the intrinsic viscosity $\left(\mu_{i}\right)$ value cannot be totally estimated. In fact, as those equations (Table 2) are sensitive to this parameter, the results may show differences.

Even though the physical properties of kaolin play a predominant role in the rheology of a mixture with non-colloidal particles, the intensity of interaction with these particles can vary according to their physical characteristics. This is shown in a graph (Figure 6B), where the line dividing the rheological behavior transition is different for the three mixtures composed of cohesive and non-cohesive material. The red dotted line indicates the transition between Newtonian and non-Newtonian behavior of the mixtures used in this work, in a blue line, the transition of rheological behavior of mixtures composed of kaolin and sand (Coussot \& Piau, 1994; Kiryu, 2006; Santos, 2003) and, in a continuous black line, the transition of rheological behavior found by Manica (2009) who worked with kaolin and glass beads.

The rheological threshold of mixtures with 100\% kaolin (bottom line) occurred for different volumetric concentrations of sediment. This difference can be explained from the use of natural kaolin from different sources, as well as by different criteria for choosing the spindle and the methodology for operating the rheometer. At the top of Figure 6B, we noticed a transition behavior for mixtures with a greater amount of coal, followed by mixtures with sand and lastly for mixtures with a greater amount of glass beads. The distance between the curves increase as the amount of kaolin in the mixture decreases, which also correspond to the value of the maximum packing fraction (Table 6). With less than $50 \%$ of kaolin present in the mixtures, the physical properties of the inert material, such as particle size distribution and particle shape, justify the increase in the maximum packaging fraction values and the distance between the curves.

Finally, the exclusive use of the equations proposed in this work is due to the fact that the relative viscosity is an intrinsic property of the material, depending on the microstructure and 
physical parameters of a mixture; therefore, the limits of the volumetric concentrations and sediment ratio should be respected, as indicated in Figures 6A and 6B.

\section{Implication for physical simulation of sediment gravity flows}

The sediment gravity flows present in nature a highly destructive behavior due to magnitude and intensity. The high velocity and thickness involved in such flows makes hard the monitoring of these flows in loco (Simpson, 1997). On the other hand, simulating these flows under controlled conditions, i.e., small-scale physical experiments, allows us to control the response to changes on every variable or parameter involved. However, the physical experiments must offer the dynamic similarity between the prototype and the model. And the use of a lower density sediment (coal; $\left.\varrho=1190 \mathrm{~kg} \cdot \mathrm{m}^{-3}\right)$ to represent the sediment gravity flows (sand quartz; $\varrho=2650 \mathrm{~kg} \cdot \mathrm{m}^{-3}$ ) can cause distortion of the results, called scale effect.

Brito (2005) states that "in order to guarantee the elimination of the scale effect, the density of the sediment used in the mixture, the conditions for its admission and also the value of the non-dimensional densiometric Froude must be kept constant". But Motta (1972) and Barenblatt (2003) are categorical in stating that a reduced scale model does not fully replicate the behavior of the studied physical phenomenon, i.e., the scale effects cannot be eliminated, but minimized.

In fact, the use of sediment with lower density in the experiments caused an increase in the volumetric concentration of sediments, as larger number of particles was injected in the mixture to keep the same density of the mixture. Consequently, the sediments can cause a possible change in rheological behavior of such mixtures, which has direct implications for the mechanisms of sediment transport and deposition. As a simple example, the volumetric concentration of the coal can be 8.7 times higher than the volumetric concentration of sand for a density of mixtures at $1076 \mathrm{~kg} \cdot \mathrm{m}^{-3}$, which leads to a distinct rheological behavior if we consider a Newtonian 5\% volumetric concentration of sand and clay compared with non-Newtonian behavior coal and clay (Figure 6B). Then, this effect should be considered on physical simulations.

\section{CONCLUSION}

The rheological (mechanical) behavior of clay and/or coal mixture suspensions which simulates sediment gravity flows in the laboratory was adjusted to the Newton and Herschel-Bulkley models. Also, this work estimates two equations for calculating relative viscosity of kaolin and/or coal suspensions (or other similar granular material) which can also be used to extrapolate the results to natural sediment gravity flows. The results show an error around $20 \%$ comparing similar models in literature, which can be considered satisfactory. However, the results also demonstrate that caution should be exercised when generalizing the use of a single model to predict the relative viscosity of suspensions. The influence of density (@), grain shape, clay percentage $\left(\mathrm{C}_{\text {clay }}\right)$, volumetric concentration $(\phi)$ and maximum packaging fraction $\left(\phi_{\max }\right)$ should be considered in the formulation of the equations. The results presented here are limited to mixtures with kaolin particles and/or coal or other sediment with physical characteristics close to those used in the elaboration of the empirical equation and should be used within the limits of the volumetric concentrations and sediment ratio.

Finally, the similarity of rheological behavior between the mixtures used in the simulation of sediment gravity flows and those of the natural environment will not be complete in all cases. The elaboration of a scale with rheological similarity should be considered, to seek an equality in the values of viscosities of the mixtures tested with those of the natural environment, as the scale impacts on flow dynamics along time and space.

\section{ACKNOWLEDGEMENTS}

Authors are thankful to the Necod team and UFRGS for allowing the use of the laboratory facilities and support throughout the undergraduate and master of science studies of the first author. Finally, the authors wish to express their gratitude Léo A. Hartmann for his assistance and comments during the preparation of this manuscript.

\section{REFERENCES}

Baas, J. H., Manica, R., Puhl, E., Verhagen, I., \& Borges, A. L. O. (2014). Processes and products of turbidity currents entering soft muddy substrates. Geology, 42(5), 371-374. http://dx.doi. org/10.1130/G35296.1.

Barenblatt, G. I. (2003) Scaling. Cambridge: Cambridge University Press. http://dx.doi.org/10.1017/CBO9780511814921.

Barnes, H. A., Hulton, J. F., \& Walters, F. R. S. (1993). An introduction to rheology (3rd ed.). Amsterdam: Elsevier.

Batchelor, G. K., \& Green, J. T. (1972). Determination of the bulk stress in a suspension of spherical particles to order c2. Journal of Fluid Mechanics, (56), 375-400.

Beruto, D. T., Lagazzo, A., Botter, R., \& Grillo, R. (2009). Yield stress measurements and microstructure of colloidal kaolin powders clusterized and dispersed in different liquids. Particuology, 7(6), 438-444. http://dx.doi.org/10.1016/j.partic.2009.06.011.

Boffo, C., Pereira, L. F., Silva, D. B., Von Ahn, B., Schwambach, R., Cerqueira, A., Borges, A. L. O., Manica, R., Oliveira, T. A., Moraes, M., \& Paraizo, P. (2019). Analysis of experimental data for determination of transport efficiency in density currents. In IAS 2019, Rome.

Brito, D. U. (2005). Efeito das escalas de simulação sobre os padrões deposicionais de fluxos turbidíticos (Dissertação de mestrado). Programa de Pós-graduação em Recursos Hídricos e Saneamento Ambiental, Universidade Federal do Rio Grande do Sul, Porto Alegre. 
Brouwers, H. J. H. (2010). Viscosity of a concentrated suspension of rigid monosized particles. Physical Review E, 81(5), 051402. PMid:20866225. http://dx.doi.org/10.1103/PhysRevE.81.051402.

Chong, J. S., Christiansen, E. B., \& Baer, A. D. (1971). Rheology of concentrated suspensions. Journal of Applied Polymer Science, 15(8), 2007-2021. http://dx.doi.org/10.1002/app.1971.070150818.

Coussot, P. (1997). Mudflow rheology and dynamics (1st ed.). Rotterdam: Taylor \& Francis.

Coussot, P., \& Piau, J. K. (1994). On the behavior of fine mud suspensions. Rheologica Acta, 73(3), 175-184. http://dx.doi. org/10.1007/BF00437302.

D’Ávila, R. S. F., \& Paim, P. S. G. (2003). Mecanismos de transporte e deposição de turbiditos. In P. S. G. Paim \& U. F. Faccini (Eds.), Geometria, arquitetura e heterogeneidades de corpos sedimentares: estudos de caso (pp. 93-121). São Leopoldo: Universidade do Vale do Rio dos Sinos.

Dabak, T., \& Yucel, P. (1986). Shear viscosity behavior of highly concentrated suspensions at low and high shear-rates. Rheologica Acta, 25(5), 527-533. http://dx.doi.org/10.1007/BF01774404.

Dasgupta, P. (2003). Sediment gravity flow: the conceptual problems. Earth-Science Reviews, 62(3-4), 265-281. http://dx.doi. org/10.1016/S0012-8252(02)00160-5.

Dott, R. H. (1963). Dynamics of subaqueous gravity depositional process. The American Association of Petroleum Geologists Bulletin, 47, 104-128.

Dougherty, T. J., \& Krieger, I. M. (1959). Potential around a charged colloidal sphere. Journal of Physical Chemistry, 63(11), 1869-1872. http://dx.doi.org/10.1021/j150581a019.

Einstein, A. (1905). Berichtigung zu meiner Arbeit: Eine neue Bestimmung der Moleküldimensionen. Annalen der Physik, 34, 591-592.

Fick, C., Manica, R., \& Toldo Junior, E. E. (2017). Autogenic influence on the morphology of submarine fans: an approach from 3D physical modelling of turbidity currents. Brazilian Journal of Geology, 47(3), 345-368. http://dx.doi.org/10.1590/23174889201720170066 .

Gani, M. R. (2004). From Turbid to Lucid: a straightforward approach to sediment gravity flows and their deposits. The Sedimentary Record, 2(3), 4-8. http://dx.doi.org/10.2110/sedred.2004.3.4.

Horri, B. A., Ranganathan, P., Selomulya, C., \& Wang, H. (2011). A new empirical viscosity model for ceramic suspensions. Chemical Engineering Science, 66(12), 2798-2806. http://dx.doi.org/10.1016/j. ces.2011.03.040.
Kiryu, H. S. (2006). Investigação reológica e análise mecânica de compósitos não-Newtonianos (Dissertação de mestrado). Faculdade de Engenharia de Ilha Solteira, Universidade Estadual Paulista, Ilha Solteira.

Liu, D. M. (2000). Particle packing and rheological property of highly-concentrated ceramic suspension: $\phi \mathrm{m}$ determination and viscosity prediction. Journal of Materials Science, 35(21), 5503-5507. http://dx.doi.org/10.1023/A:1004885432221.

Lowe, D. R. (1979). Sediment gravity flows: their classification and some problems of application to natural flows and deposits. SEPM, 27, 75-82. http://dx.doi.org/10.2110/pec.79.27.0075.

Lowe, D. R. (1982). Sediment gravity flows: II. Depositional models with special reference to the deposits of high-density turbidity currents. Journal of Sedimentary Petrology, 52(1), 279-297.

Manica, R. (2002). Modelagem física de correntes de densidade não conservativas em canal tridimensional de geometria simplificada (Dissertação de mestrado). Universidade Federal do Rio Grande do Sul, Porto Alegre.

Manica, R. (2009). Geração de correntes de turbidez de alta densidade: condicionantes hidráulicos e deposicionais (Tese de doutorado). Program in Water Resources and Environmental Sanitation, Universidade Federal do Rio Grande do Sul, Porto Alegre.

Manica, R., \& Borges, A. L. O. (2015). Caracterização geométrica de deltas dominados por rios simulados experimentalmente sob variação de condições de aporte fluvial e nível de base. Geociencias, 24(4), 733-748.

Maron, S. H., \& Pierce, P. E. (1956). Application of ree-eyring generalized flow theory to suspensions of spherical particles. Journal of Colloid Science, 11(1), 80-95. http://dx.doi.org/10.1016/00958522(56)90023-X.

Middleton, G. V., \& Hampton, M. A. (1973). Part 1. Sediment gravity flows: mechanics of flow and deposition. In: G. V. Middleton \& A. H. Bouma (Eds.), Turbidites and deep-water sedimentation (pp. 1-38). Anaheim, CA: SEPM Pacific Section Short Course.

Motta, V. F. (1972). Curso de Teoria da Semelhança. Porto Alegre: Ed. URGS.

Mulder, T., \& Alexander, J. (2001). The physical character of subaquaeous sedimentary density flows and their deposits. Sedimentology, 48(2), 269-299. http://dx.doi.org/10.1046/j.13653091.2001.00360.x.

Normark, W. R., Posamentier, H., \& Mutti, E. (1993). Turbidite systems: state of the art future directions. Reviews of Geophysics, 31(2), 91-116. http://dx.doi.org/10.1029/93RG02832.

Pabst, W. (2004). Fundamental consideration on suspension rheology. Journal Ceramics-Silikáty, 48(1), 6-13. 
Postma, G., Nemec, W., \& Kleinspehn, K. L. (1988). Large Floating clats in turbidites: a mechanism for their emplacement. Sedimentary Geology, 58(1), 47-67. http://dx.doi.org/10.1016/00370738(88)90005-X.

Rutgers, I. R. (1962). Relative viscosity of suspensions of rigid spheres in Newtonian liquids. Rheologica Acta, 2(3), 202-210. http:/ / dx.doi.org/10.1007/BF01983952.

Santamaría-Holek, I., \& Mendoza, C. I. (2010). The rheology of concentrated suspensions of arbitrarily-shaped particles. Journal of Colloid and Interface Science, 346(1), 118-126. PMid:20303498. http://dx.doi.org/10.1016/j.jcis.2010.02.033.

Santos, F. L. (2003). Estudo teórico-experimental em via de determinação de lei de atrito em escoamentos de fluidos hiperconcentrados (Dissertação de mestrado). Faculdade de Engenharia de Ilha Solteira, Universidade Estadual Paulista, Ilha Solteira.

Schleiss, A. J., Franca, M. J., Juez, C., \& De Cesare, G. (2016). Reservoir sedimentation. Journal of Hydraulic Research, 54(6), 595614. http://dx.doi.org/10.1080/00221686.2016.1225320.

Shanmungan, G. (1996). High-density turbidity currents: are they sandy debris flows? Journal of Sedimentary Research, 66(1), 2-10. http:/ / dx.doi.org/10.1306/D426828E-2B26-11D7-8648000102C1865D.
Simpson, E. J. (1997). Gravity currents in the environment and the laboratory (2nd ed.). Cambridge: Cambridge University.

Talling, P. J., Masson, D. G., Sumner, E. J., \& Malgesini, G. (2012). Subaqueous sediment density flows: depositional processes and deposit types. Sedimentology, 59(7), 1937-2003. http://dx.doi. org/10.1111/j.1365-3091.2012.01353.x.

\section{Authors contributions}

Camila Castro: Run the experiments, analysis and wrote the manuscript.

Ana Luiza de Oliveira Borges: Was Camila Castro supervisor on the master of science study and review the text.

Rafael Manica: Was co-supervisor of Camila Castro and review the text and discussions.

Editor-in-Chief: Adilson Pinheiro

Associated Editor: Iran Eduardo Lima Neto 